動的載荷時における鉄筋コンクリート造卜形柱梁接合部の 力学的性状に関する研究

\title{
STUDY ON THE MECHANICAL PROPERTIES OF REINFORCED CONCRETE EXTERIOR BEAM-COLUMN JOINTS UNDER DYNAMIC LOADING
}

\author{
小川 勤*, 北嶋圭二**, 中西三和***, 安達 洋***, 青山博之**** \\ Tsutomu OGAWA, Keiji KITAJIMA, Mitsukazu NAKANISHI, \\ Hiromi ADACHI and Hiroyuki AOYAMA
}

\begin{abstract}
Dynamic and static loading tests were conducted to evaluate the seismic performance of reinforced concrete exterior beam-column joint at the lower story of high-rise buildings. Eight sets of two specimens each with the same dimensions and details were prepared for the dynamic and static tests. Variable parameters of these specimens were three, that is, (1) ratio of the ultimate shear strength of the beam-column joint to the bending yield strength of beam, (2) anchoring method of main reinforcements of beam : mechanical anchor and $U$ shaped anchor, (3) axial load of column : constant axial load and fluctuating axial load. Influence of loading rate increase on the failure process, ultimate strength and deformation performance was investigated, comparing the dynamic and static test results under various conditions.
\end{abstract}

Keywords : Reinforced concrete exterior beam-column joints, Static loading tests, Dynamic loading tests, U-shaped anchor, Mechanical anchor, Shear capacity, Fluctuating axial load

鉄筋コンクリート造ト形柱梁接合部，静的載荷実験，動的載荷実験，U 字形定着，機械式定着，せん断余裕度，変動軸力

\section{1.はじめに}

近年, 鉄筋コンクリート造(以下 $\mathrm{RC}$ 造)建物の高層化に伴い, 高 強度材料の使用が普及するとともに，柱梁部材の断面を著しく増大 させることなく建物を高層化することが可能となった。しかし，そ のことが相対的に接合部断面を縮小化し, その結果, 接合部パネル 部のせん断応力度が相対的に大きくなり，接合部が骨組内で弱点と なることが指摘された ${ }^{1)} 。 1995$ 年の兵庫県南部地震でも，比較的新 しい RC 造建物で，柱梁接合部に被害を受けた例がいくつか報告さ れている ${ }^{2)}$ えこのことから，地震時での柱梁接合部の破壊挙動を把 握し，接合部の各種限界状態における損傷を詳細に評価することは 建物を設計する上で重要な課題である。

一方， RC 造卜形接合部を対象として考えると，接合部断面の縮 小化亡高強度鉄筋などの使用は，従来の梁主筋の折曲げ定着を困難 な状態にしている。しかし，近年では，接合部内の高密度な配筋を 緩和し，施工を省力化する目的から，定着金物などを用いた機械式 定着法が開発され，性能確認のための静的な載荷実験によって従来 の折曲げ定着と同等の定着性能を持つことが確認されている ${ }^{3), 4,5)}$ 。 しかし，地震時における挙動を直接再現できるような動的載荷実験 によって, 載荷速度が定着性能に及ぼす影響を調べた研究は少なく, 未だ不明な点がある。また，高層 $\mathrm{RC}$ 造建物の下層部外柱では，地
震時に作用する転倒モーメントにより, 大きな軸力の変動を受ける。 これは，柱の一部である接合部においても同様であり，変動軸力が 柱梁接合部の性能に影響を与える可能性が指摘される。しかし，軸 力の変動を伴うような RC 造柱梁接合部を対象に載荷速度の影響を 調べるために動的載荷実験を実施した例はこれまでにない。

このような背景から筆者らは，高層 RC 造建物の下層部卜形柱梁 接合部を対象とし，接合部の動的及び静的載荷実験を実施し，接合 部の破壊挙動, 耐力，変形性能を詳細に調べた ${ }^{6), 7), 8,99 。 こ れ ら は 一 ~}$ 貫したシリーズの実験であり，静的及び動的載荷実験を一対とし， (1)接合部せん断余裕度（梁曲げ降伏強度と接合部せん断強度の比）, (2)接合部内の梁主筋定着法（機械式定着と $U$ 字形定着)，(3)柱軸力 （一定軸力と変動軸力）を実験因子とした試験体を対象とした。

本論文は, これら種々の条件下における実験結果について, 載荷 速度の上昇が接合部の破壊状況, 耐力, 変形性能に及ぼす影響を明 らかにしたものである。

\section{2. 実卧根要}

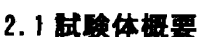

本実験で想定した構造物と試験体の応力状態の概念図を図 1 に示 す。また, 試験体一覧を表 1 に, 試験体形状と配筋例を図 2 に示す。

\footnotetext{
$*$ 日本大学大学院理工学研究科 大学院生 $\cdot$ 工修

**青木あすな万建設侏技術研究所建築研究室 室長・工博

*** 日本大学理工学部海洋建築工学科 教授 $\cdot$ 工博

**** 青山研究室 東京大学 名誉教授・工博
}

Graduate Student, Graduate School of Science \& Technology, Nihon Univ, M. Eng. Manager, Building Technology Laboratory, Institute of Technology, Asunaro Aoki Construction Co., Ltd., Dr. Eng.

Prof., Dept. of Oceanic Architecture and Engineering, College of Science and Technology, Nihon Univ., Dr. Eng.

Prof. Emeritus, Univ. of Tokyo, Aoyama Laboratory, Dr. Eng. 
各試験体の鉄筋とコンクリートの材料強度を表 2 に示す。試験体は, 図 1 に示すように, 高層 RC 造建物の下層部外柱梁接合部を対象と したト形柱梁接合部試験体であり，これを図 2 に示すように $90^{\circ}$ 回 転させ，試験体の縮尺を約 $1 / 3$ に想定し，形状・法を定めて実験 した。なお，実構造物での側柱では変動軸力が作用し，部材に生ず る曲げモ一メント分布の反曲点は常に変化するが, 実験では梁及び 上下層の柱とも反曲点が部材中央にあると仮定した。また, 使用材 料は本来であれば高強度を用いるべきところであるが，加力装置等 の制約から D19（SD490）の鉄筋以外は通常使用の強度を持つ材料 とした。試験体は表 1 に示すように, 載荷速度が接合部に及ぼす影 響を調べるため, 動的載荷実験（D）と静的載荷実験（S）を一対と する計 16 体である。各試験体の実験因子を整理すると, (1)梁端部曲 げ降伏が先行するように設計したせん断余裕度が大きい N タイプ と, 接合部せん断強度と梁曲げ強度が拮抗するせん断余裕度が小さ いB タイプの試験体である。両タイプの試験体で, (2)接合部内の梁 主筋定着法が機械式（M）とU 字型（U）の 2 種類，(3)柱の載荷方 法が一定軸力（C）上変動軸力（V）の 3 つの因子に分けられる。な お，試験体名は，これら４つの実験変数を英文字で表現しており，

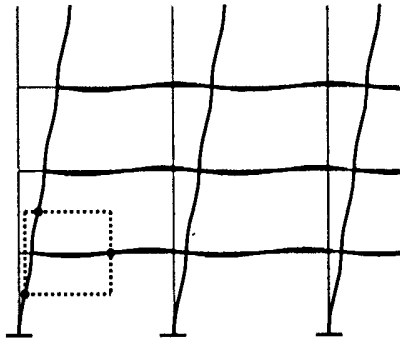

【想定建物の下層部】
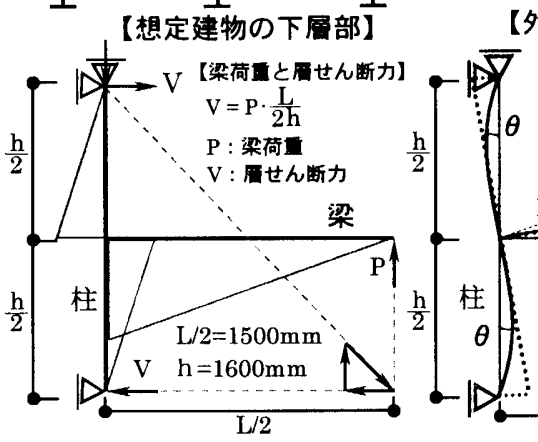

外柱梁接合部の変形】

$\delta_{\mathrm{b}}:$ 梁变形 $\delta_{c}:$ 柱と接合部变形 $\mathrm{R}$ : 部材角

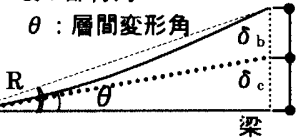

※実糇結果を評価する陆の原 间変形の詳細は, 図 7 に示す。

【ト形梁接合部試験体の応力状態】【ト形梁接合部試験体の変形】 図 1 応力状態概念図

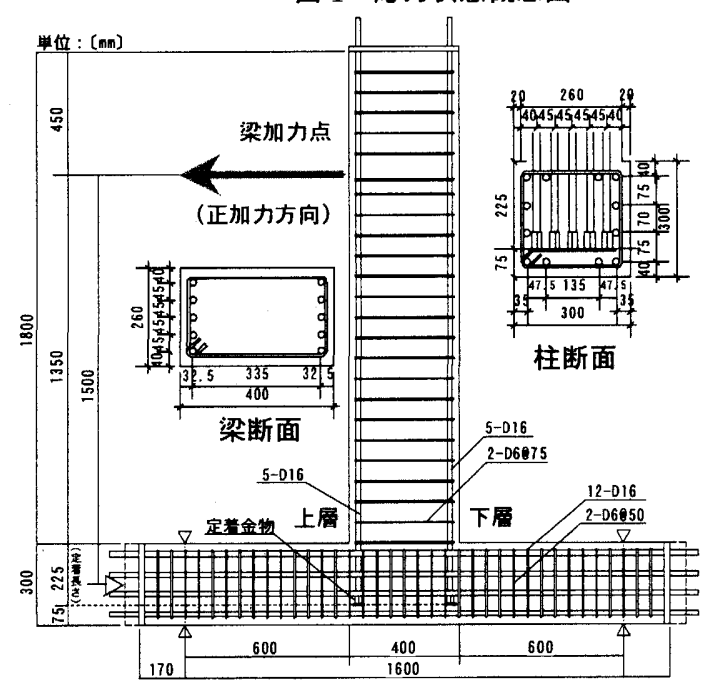

図 2 試験体形状と配筋例（BMVS 試験体）
頭文字から順に, 接合部せん断余裕度 ( $\mathrm{N}$ 又は $\mathrm{B}$ ), 接合部内の梁主 筋定着法 ( $\mathrm{M}$ 又は $\mathrm{U}$ ), 柱軸力 ( $\mathrm{C}$ 又は $\mathrm{V})$, そして載荷速度（ $\mathrm{S}$ 又 は D）を表している。図 2 に示す試験体形状寸法の内, 柱断面寸法 $300 \mathrm{~mm} \times 300 \mathrm{~mm}$, 梁断面寸法 $260 \mathrm{~mm} \times 400 \mathrm{~mm}$ は, 全試験体共通で ある。機械式定着を用いた試験体の定着長は柱せいの $3 / 4$ とした。 これにあわせるため, U 字形定着の定着長（定着投影長さ）は柱せ いの 3/4+鉄筋径とした。

\section{2 加力方法}

加力装置を図 3 に変動軸力に対する動的載荷時の加力スケジュー ルを図 4 に示す。梁の水平力はアクチュエータ(1)により図 4（a）に 示す予め指定した梁の変位を自動制御することにより載荷した。ま た，柱軸力は挺子（1：3.5）を介して，アクチュエータ(2)により同 図（b）に示す指定した荷重を自動制御することにより載荷した。な お, 反力壁側（図 3）の柱軸力は, 制御軸力值に梁のせ九断力を加 えた值となる。

柱に長期一定軸力を載荷する実験では，表 1 に示す所定の軸力を 載荷した状態で梁加力点に, 図 4 (a) に示すように, 部材角 $1 / 400$, $1 / 300 ， 1 / 200 ， 1 / 150 ， 1 / 100 ， 1 / 50$ ，を各 3 サイクル，1/25 を 2 サイ クルの繰り返し載荷スケジュールに基づいて水平力を載荷する。な お，部材角は図 1 に $\mathrm{R}$ として示すように加力点変位を加力点までの 長さ $\mathrm{L} / 2$ で除した值とした。また試験体の梁に作用させた水平力 $\mathrm{P}$ と外柱のせん断力 $\mathrm{V}$ との関係は, $\mathrm{V}=\mathrm{P} \cdot \mathrm{L} / 2 \mathrm{~h}$ である。

柱に変動軸力を載荷する実験では，まず長期一定軸力まで圧縮軸 力を加え, その後, 梁の水平変位に対応させて柱軸力を変動した。 なお，梁の水平力が正加力方向の時に柱軸力を引張軸力とした。 軸力の変動する範囲については, 30 階建て RC 造建物のフレーム系 地震応答解析 ${ }^{12)}$ を行い，地震時に高層 $\mathrm{RC}$ 造建物の下層部外柱に作 用する変動軸力を調べた。これらの解析例では，下層外柱には軸力 比にして圧縮で約 0.56 , 引張側で約 0.1 までの軸力が作用する結果 が得られた。ここでは圧縮, 引張ともに軸力比 $(n)$ は圧縮耐力に 対する比（ $\eta=\mathrm{N} / \mathrm{F}_{\mathrm{C}} \mathrm{A}_{\mathrm{C}}, \quad \mathrm{N}$;軸力， $\mathrm{F}_{\mathrm{C}}$ : コンクリート設計基準強度， $\mathrm{A}_{C}$ :柱断面積）として定義した。

この解析例を参考に，次の仮定を設け，梁の制御水平変位量に対 して作用軸力の載荷履歴を決定した。(1)想定建物は RC 造 30 階建て 程度の左右対称の建物で, 1 次モードで振動し, 層せん断力に比例 して軸力は変動するとする。このとき, 左右外柱の軸力変動量の絶 
対値は等しい。（図 5 に軸力-層せん断力関倸を示す。）(2)想定建物は 全層の層間変形角が $1 / 150$ で全体崩壞形を形成するとする。従って, 梁のせん断力は, その時点で頭打ちになり, 軸力の增加及び減少も 頭打ちになるとする。(3)想定建物の下層部分の層せん断力-層間変形 角関係は，剛性低下型の復元力特性（武田モデル）で表せるとする。

(図 6 に層せ九断力-層間変形関係を示す。) (4)長期軸力相当の軸力 比は 0.175 とし, 圧縮及び引張の各最大軸力は, 軸力比にして圧縮 で 0.55 , 引張で 0.2 とする。従って, 軸力の変動量は圧縮と引張で 同じ（ $\eta=0.175 \pm 0.375 ）$ となる。

表 3 に動的加力スケジュールを示す。動的載荷実験における梁の 変位波形は, 最大速度 50kine 相当の入力波を用いた質点系地震応答 解析により, 対象構造物の最大層間変形速度を 10kine であるとし, 以下に示す（1），(2）式により梁部材の最大変位速度及び固有円振 動数を算出し，（3）式の振幅波形を決定した。

$$
\begin{aligned}
& V_{G \max }=V_{C \max } \cdot(L / 2 h) \quad\left(V_{C \max }=\text { 一定 }\right) \\
& \omega=V_{G \text { max }} / \delta_{G}
\end{aligned}
$$
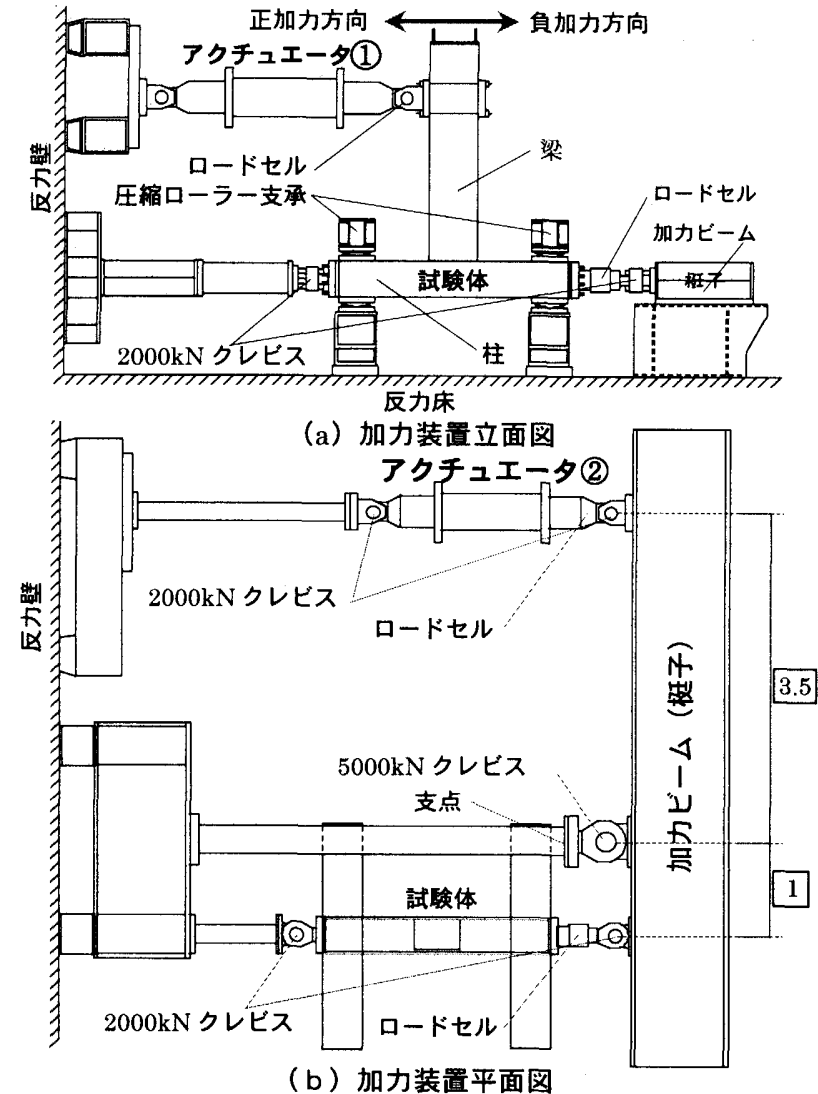

(b) 加力装置平面図

図 3 加力装置図

$$
y=\delta_{G} \sin \omega t
$$

ここに $V_{C_{\text {max }}}$ : 最大層間変形速度 $(=10 \mathrm{kine}), \quad V_{G \text { max }}$ : 最大梁変位 速度 $(=9.375 \mathrm{kine}), L$ : 梁長さ, $h$ : 柱長さ, $\delta_{G}$ : 梁の振幅（な お, 振幅は, 各部材角で層間変位が決定し, 柱と梁の長さの関係に より算出される。また, 図 4(a)のように振幅は漸増する。), $\omega$ ：固 有円振動数である。静的載荷実験においては, 動的載荷の加力スケ ジュールに準じて載荷速度を $1 / 1000$ 倍にして行った。また動的及び 静的載荷実験ともに部材角 $1 / 25$ までの正負繰返し載荷を基本とし, 静的載荷実験では部材角 $1 / 25$ で耐力低下を起こしていない試験体 については, 最終破壊状況を確認するため部材角 $1 / 12$ まで載荷した。

\section{3 睍定項目}

本実験での測定項目および測定方法を以下に示す。梁の水平荷重 はアクチュエータ付属のロードセルで, 柱軸力は $2000 \mathrm{kN}$ ロードセ ルで, 梁変位 $(\mathrm{X} 1)$, 柱梁節点角に伴う変位 $(\mathrm{X} 2, \mathrm{X} 3)$, 接合部パネ ルの鉛直 $(\mathrm{X} 4, \mathrm{X} 5)$ ，水平 $(\mathrm{X} 6, \mathrm{X} 7)$ 及び対角 $(\mathrm{X} 8, \mathrm{X} 9)$ 相対変位は ストローク式変位計で計測した。これら測定変位 $\mathrm{X} 1$ 1 X9 における 部材変形の概念図 ${ }^{13)}$ を図 7 に示した。また, 定着部を含む梁主筋, 柱主筋及び接合部横補強笳のひずみをひずみゲージで計測した。

\section{3. 实㯺结果}

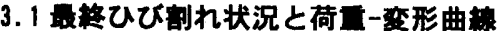

【Nシリースの実駛】図 8 に N シリーズにおける最終ひび割れ発生
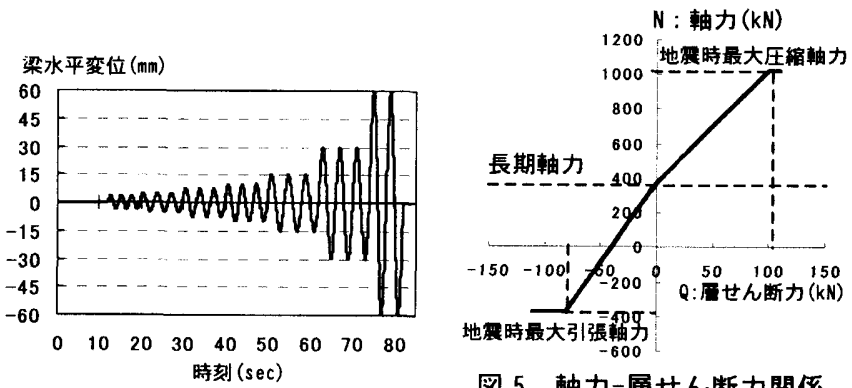

(a) 梁変位

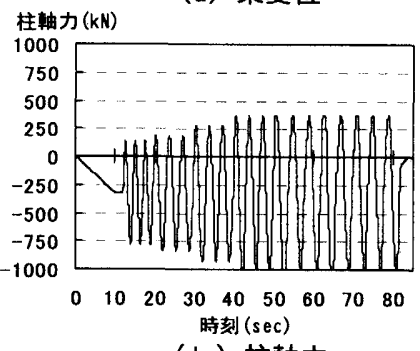

図 5 軸力-層せん断力関係

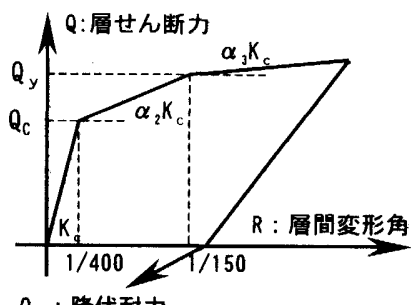

(b) 柱軸力

$Q_{c}:$ ひび割れ耐力 $\left(Q_{c}=2 / 3 Q_{y}\right)$

$\mathrm{K}_{\mathrm{c}}$ : 第 1 㓮性 $\alpha_{2}$ : 第 2 剧性低下率 $\alpha_{3}:$ 第 3 㣚性低下率 $(=0.001)$

図 4 柱及び梁の加カスケジュール

\begin{tabular}{|c|c|c|c|c|c|c|c|c|c|}
\hline \multirow[b]{2}{*}{ 試験体 } & \multicolumn{5}{|c|}{ 鉄 筋 } & \multicolumn{4}{|c|}{ コンクリート } \\
\hline & 径 & $\begin{array}{l}\text { 降伏強度 } \\
\left(\mathrm{N} / \mathrm{mm}^{2}\right)\end{array}$ & $\begin{array}{c}\text { 降伏強度時の } \\
\text { ひずみ }(\mu)\end{array}$ & $\begin{array}{l}\text { ヤング係数 } \times \\
10^{5}\left(\mathrm{~N} / \mathrm{mm}^{2}\right)\end{array}$ & $\begin{array}{l}\text { 引張強度 } \\
\left(\mathrm{N} / \mathrm{mm}^{2}\right)\end{array}$ & $\begin{array}{c}\text { 設計基準 } \\
\text { 強度 }\left(\mathrm{N} / \mathrm{mm}^{2}\right)\end{array}$ & $\begin{array}{l}\text { 压縮強度 } \\
\left(\mathrm{N} / \mathrm{mm}^{2}\right)\end{array}$ & $\begin{array}{c}\text { 圧縮強度時の } \\
\text { ひずみ }(\mu)\end{array}$ & $\begin{array}{l}\text { ヤング係数 } \times \\
10^{4}\left(\mathrm{~N} / \mathrm{mm}^{2}\right)\end{array}$ \\
\hline \multirow{2}{*}{$\begin{array}{l}\text { NMC } \\
\text { NUC }\end{array}$} & D19 & 587 & (2863) & $(2.05)$ & 803 & \multirow{2}{*}{30} & \multirow{2}{*}{42.4} & \multirow{2}{*}{ - } & \multirow{2}{*}{$(2.44)$} \\
\hline & D10 & 420 & (2049) & (2.05) & 525 & & & & \\
\hline \multirow{2}{*}{$\begin{array}{c}\text { NMV } \\
\text { BMC BMV }\end{array}$} & D16 & 392 & (1912) & $(2.05)$ & 591 & \multirow{2}{*}{21} & \multirow{2}{*}{25.8} & \multirow{2}{*}{ - } & \multirow{2}{*}{ (2.17) } \\
\hline & D6 & 333 & (1624) & $(2.05)$ & 487 & & & & \\
\hline \multirow{3}{*}{$\begin{array}{c}\text { NUV } \\
\text { BUC BUV }\end{array}$} & D16 & 388 & 2022 & 1.94 & 599 & \multirow{3}{*}{21} & \multirow{3}{*}{18.6} & \multirow{3}{*}{1758} & \multirow{3}{*}{2.54} \\
\hline & D13 & 373 & 1894 & 2.02 & 526 & & & & \\
\hline & D6 & 402 & 1988 & 2.02 & 560 & & & & \\
\hline
\end{tabular}

図 6 層せん断力-層間変形関係

表 2 材料試験結果一覧

\begin{tabular}{|c|c|c|c|c|}
\hline 部材角 & 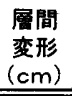 & $\begin{array}{c}\text { 梁加力 } \\
\text { 点振幅 } \\
(\mathrm{cm}) \\
\end{array}$ & $\begin{array}{c}\text { 固有円 } \\
\text { 振動数 } \\
(\mathrm{rad} / \mathrm{sec}) \\
\end{array}$ & $\begin{array}{l}\text { 周期 } \\
(\mathrm{sec}) \\
\end{array}$ \\
\hline $1 / 400$ & 0.40 & 0.38 & 25.00 & 0.25 \\
\hline $1 / 300$ & 0.53 & 0.50 & 18.75 & 0.34 \\
\hline $1 / 200$ & 0.80 & 0.75 & 12.50 & 0.50 \\
\hline $1 / 150$ & 1.07 & 1.00 & 9.38 & 0.67 \\
\hline $1 / 100$ & 1.60 & 1.50 & 6.25 & 1.01 \\
\hline $1 / 50$ & 3.20 & 3.00 & 3.13 & 2.01 \\
\hline $1 / 25$ & 6.40 & 6.00 & 1.56 & 4.02 \\
\hline
\end{tabular}

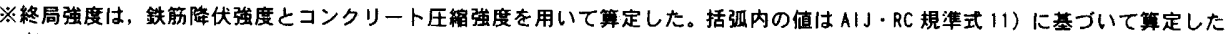
値である。また，実駼値のないものは空欄とした。

※最大層间変形速度：10kine，最大梁変位速

度 : $9.375 \mathrm{kine}$ と仮定する 


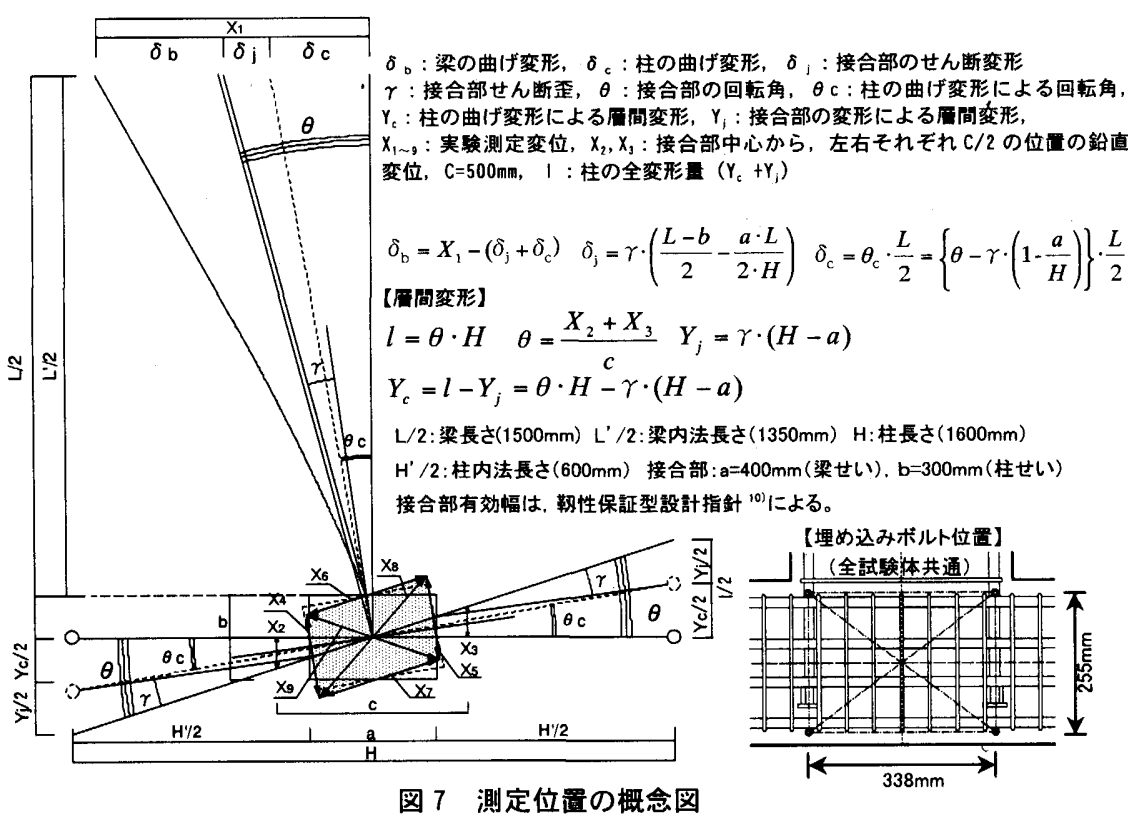

状況（梁，柱，接合部及び柱背面部）と梁の水平 荷重-梁の部材角曲線を示した。同図には梁主筋, 柱主筋及び接合部横補強筋の降伏状況を併せて示 した。以下に，載荷方法の違いによる部材挙動の 差異を軸力変動の有無と定着方法の違いの関係で 考察する。なお，以降断りのない限り，荷重及び 変形（部材角）は，梁加力点位置に載荷した水平 力とその位置で測定した水平変位とする。

\section{1）一定竞力（C）下における部材挙功の特微}

各試験体の破壊過程は，梁曲げひび割れ発生， その後の梁主筋降伏と接合部せん断ひび割れ発生 までは同様であるが, 部材角 $1 / 12$ で NMCS, NMCD, NUCS 試験体では，梁主筋の押し出しによって柱 背面のかぶりコンクリートが最終的に大きく剥離 している。定着方法による破壊性状の最も大きな 差巽は，載荷速度に拘らず機械式定着の NMCS， NMCD で，接合部外側の柱主筋に浻う割裂状のひ び割れが発生することである。全試験体における
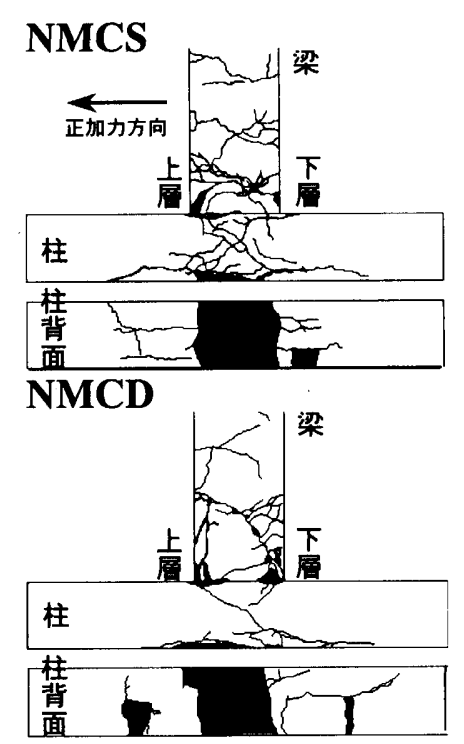

NUCS
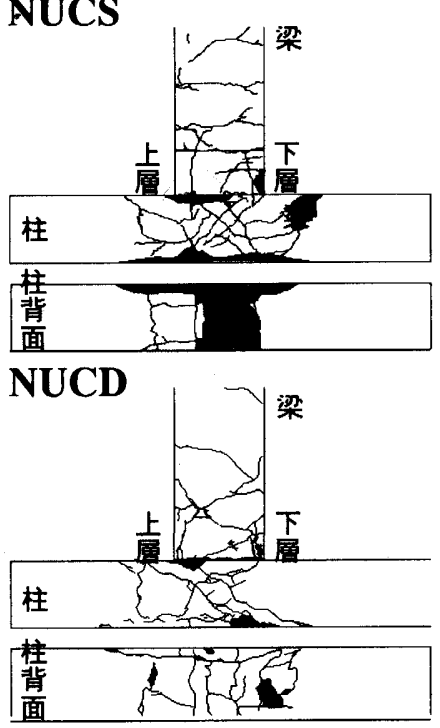

【最終ひび割れ状況】

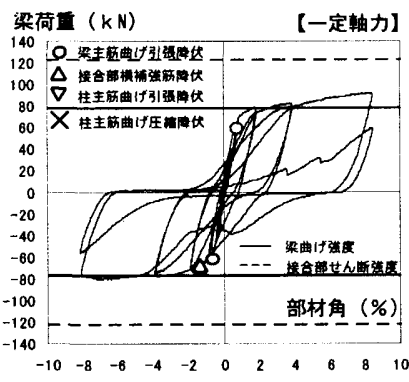
梁荷 $(\mathrm{kN})$
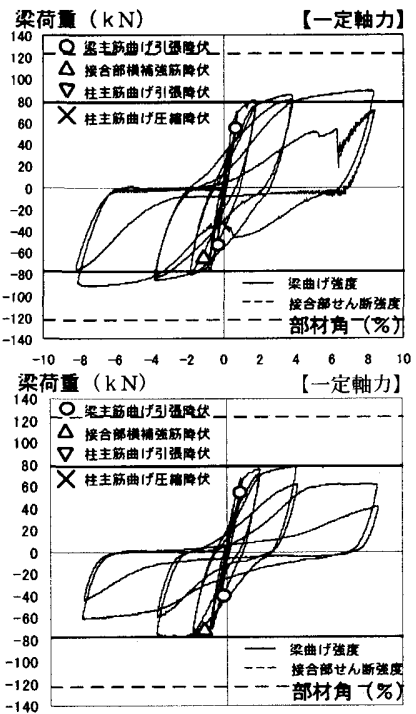

梁渮重 $^{-8}\left(k^{-6}\right)$

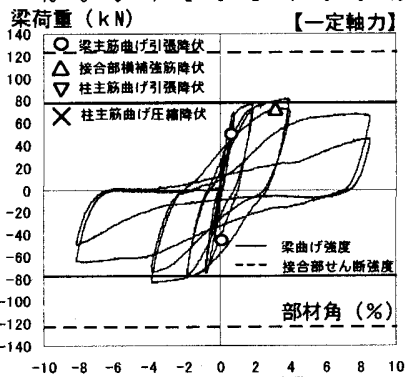

【何重一変形曲線】

図8 N シリーズにおける取
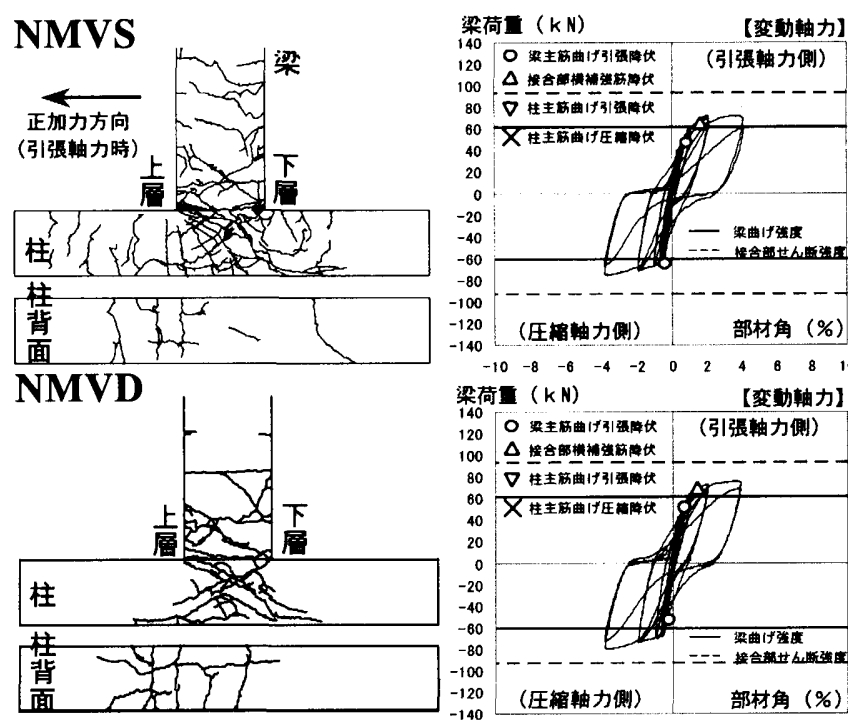

NUVS
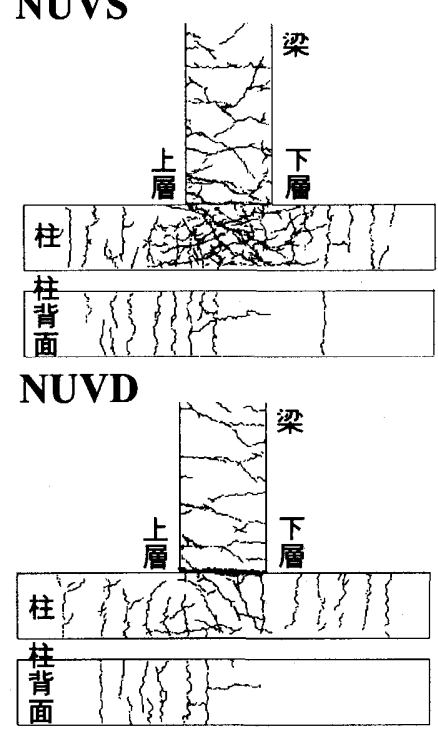

【最終ひび割れ状況】

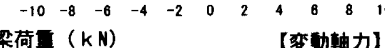

○ (

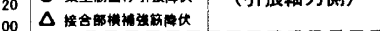

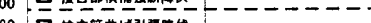

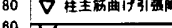

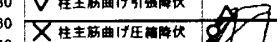

20

0
-20
-40

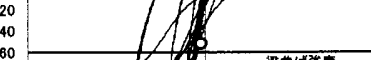

(压綿軸力側) 部材角 (\%) 梁荷董 $(\mathrm{kN})$ 【変動䖝力)

等

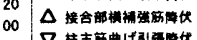

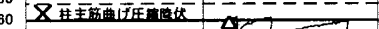
40

20

-20
-40
-10

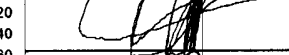

Lon
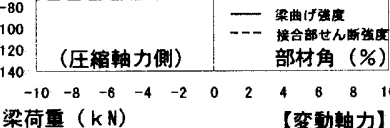

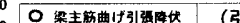

(引張轴力側)

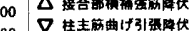

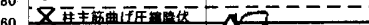

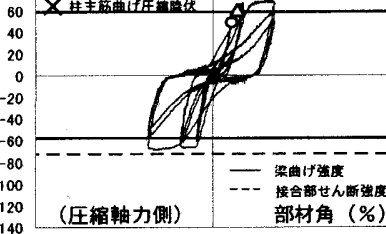

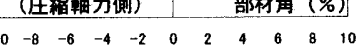
【荷重一変形曲線】

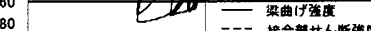

$\begin{array}{llllllllllll}-10 & -8 & -6 & -4 & -2 & 0 & 2 & 4 & 6 & 8 & 10\end{array}$

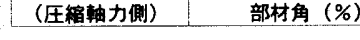


静的と動的の比較では, 動的載荷における試験体のひび割れが少な く，破壊が特定のひび割れに集中する傾向にある。U 字形定着の NUCD では, NUCS に比べ, 接合部内の定着部近傍及び柱背面の破 壊が若干軽微になる。

全試験体では梁主筋が曲げ降伏した後に接合部横補強筋が降伏し， 梁曲げ降伏後に接合部が破壊し, 荷重-変形曲線は, 静的及び動的と もに紡鍾形の履歴性状を示した。なお, 機械式定着の NMCS, NMCD では, 部材角 $1 / 12$ の 2 回目の加力時に梁主筋の押し出しによる柱背 面の破壊で載荷中に荷重が低下する不安定な状態が観測された。ま た全試験体の最大耐力は静的より動的載荷時の方が大きくなった。

\section{2）变动款力（V）下における部材举功の特晚}

変動軸力の試験体（NMVS, NUVS, NUVD）では引張軸力側で柱 材軸に直角方向に入る引張ひび割れが特徵的であり，一定軸力の試 験体より接合部のひび割れ本数が多く破壊が顕著である。

動的載荷の試験体（NMVD，NUVD）では静的よりも接合部の破 壊は明らかに軽微になり梁端部に破壊が集中する。また，機械式定 着の試験体（NMVS, NMVD）では, 柱主筋に沿うひび割れの発生 がみられるが，一定軸力の試験体ほど顕著ではない。
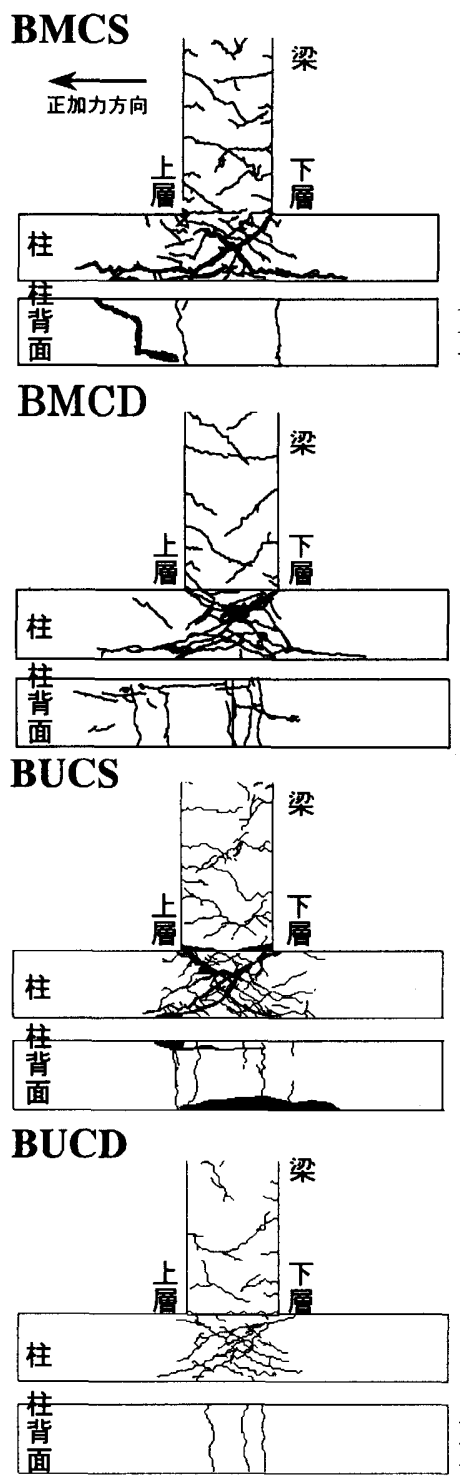

【最終ひび割れ状況】
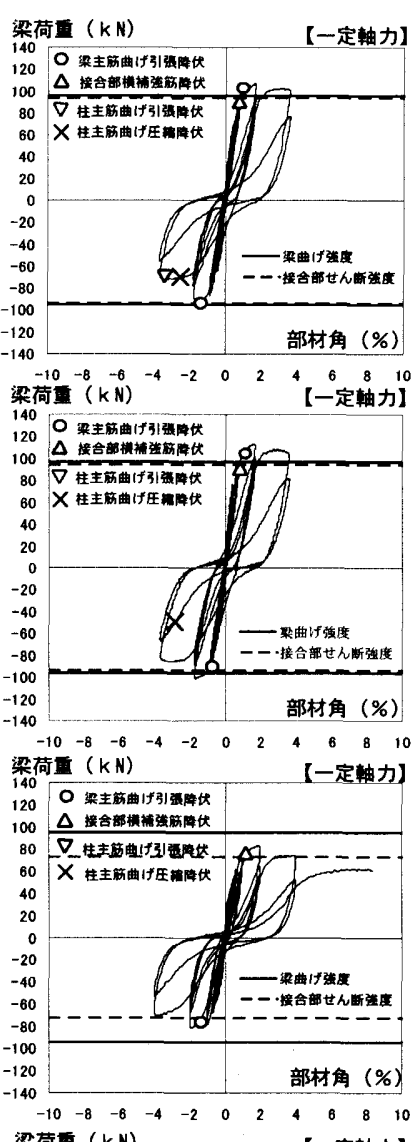
梁荷重 $(k N)$

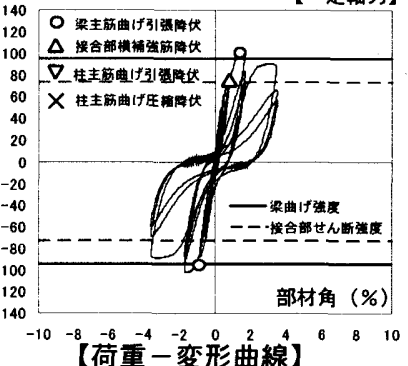

【荷重一変形曲線】
最大耐力までは各試験体とも履歴性状は一定軸力と同じ紡錘形 のループ性状を示すが, 最大耐力後では, 変動軸力下の NMVS, NMVD，NUVS，NUVD はスリップが顕著になった。また，これら の試験体は引張軸力下で梁主筋の降伏後に接合部の横補強筋が降伏 している。これは接合部の破壊が一定軸力下よりも顕著であること に符合する。変動軸力下の動的載荷実験では引張軸力側, 圧縮軸力 側ともに, 最大耐力が静的載荷時に比べ上昇した。

【B シリースの実硂】図 9 に B シリーズにおける最終ひび割れ発生 状況と荷重-変形曲線を示し, $\mathrm{N}$ シリーズと同様の検討を行う。

\section{1）一定刺力（C）下における部材誉動の特徽}

機械式定着の BMCS，BMCD は接合部で発生したひび割れが接合 部外側の柱主筋に沿って伸びたが，U 字形定着の BUCS，BUCD で は，このひび割れは発生せず接合部のひび割れが開口し最終破壊に 至っている。これらの傾向は載荷速度に拘わらず同様であるが，動 的載荷時ではひび割れ本数が少なく破壊が特定のひび割れに集中す る。各試験体とも荷重-変形曲線は静的及び動的載荷時ともに逆 $\mathrm{S}$ 字 形の履歴性状を示し，接合部横補強筋が降伏した後に梁主筋が曲げ 降伏した。最大耐力は静的より動的載荷時の方が大きくなった。
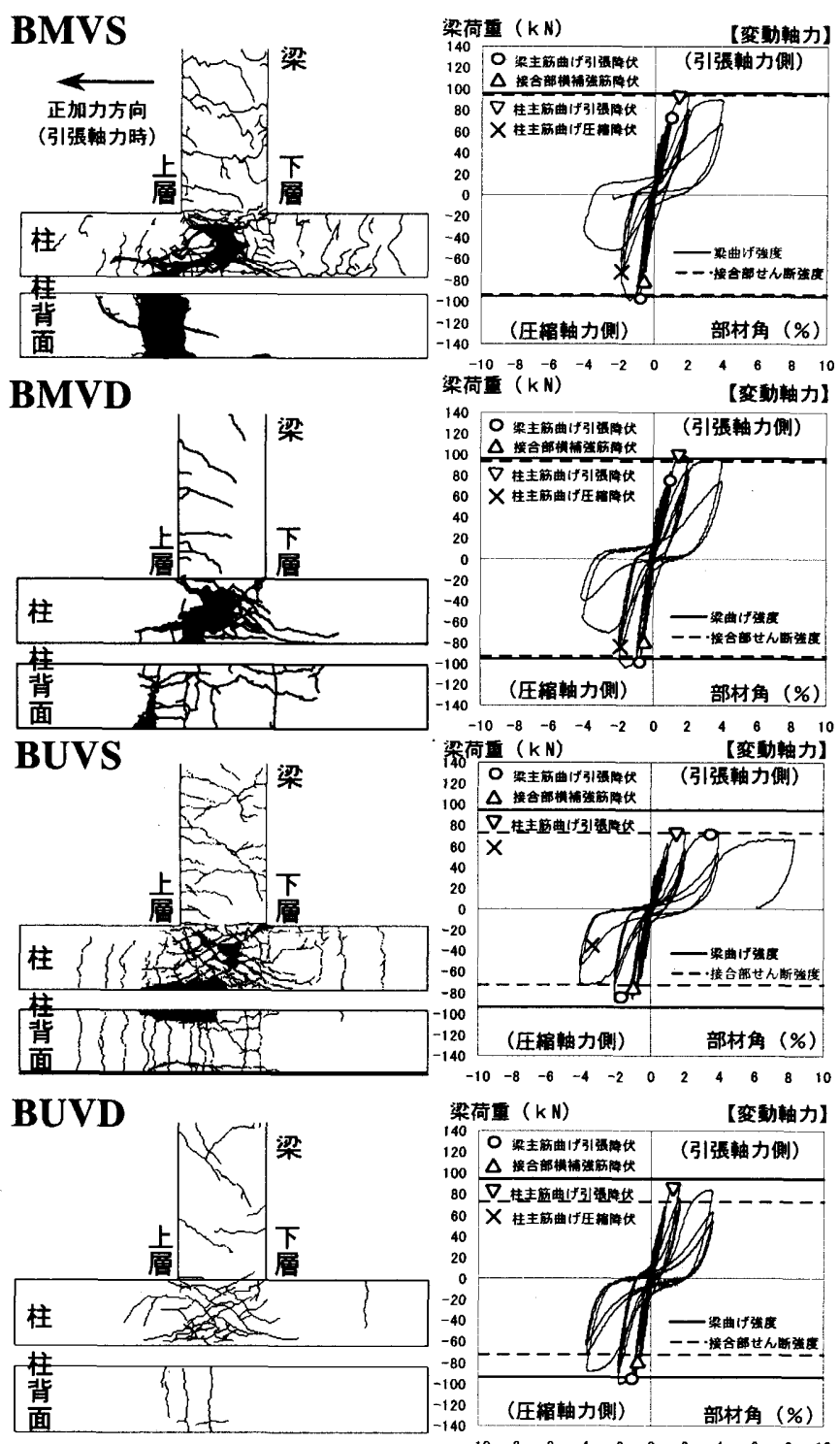

【最終ひび割れ状況】

$\begin{array}{llllllll}-4 & -2 & 0 & 2 & 4 & 6 & 8\end{array}$
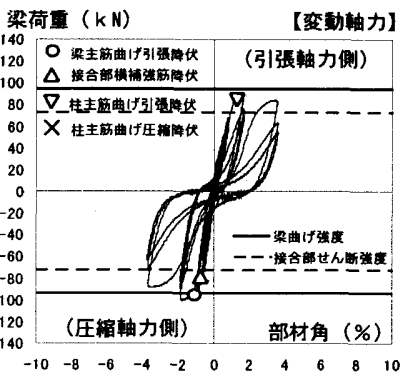

【荷重一变形曲線】 
表 4 動的載荷時におけるひずみ速度の最大値

\begin{tabular}{|c|c|c|c|c|c|}
\hline \multicolumn{2}{|c|}{ 試験体(Nタイプ) } & NMCD & NUCD & NMVD & NUVD \\
\hline \multirow{2}{*}{$\begin{array}{c}\text { ひずみ速度 } \\
(1 / \mathrm{sec})\end{array}$} & 鉄筋 & 0.441 & 0.305 & 0.264 & 0.0871 \\
\hline & コンクリート & -0.0718 & -0.102 & -0.0241 & -0.0464 \\
\hline \multicolumn{2}{|c|}{ 試験体(Bタイプ) } & BMCD & $\overline{B U C D}$ & $\overline{\overline{B M V D}}$ & $\overline{\text { BUVD }}$ \\
\hline \multirow{2}{*}{$\begin{array}{c}\text { ひずみ速度 } \\
(1 / \mathrm{sec}) \\
\end{array}$} & 鉄筋 & 0.122 & 0.124 & 0.229 & 0.00607 \\
\hline & コンクリート & -0.00826 & -0.00748 & -0.008263 & -0.00523 \\
\hline
\end{tabular}

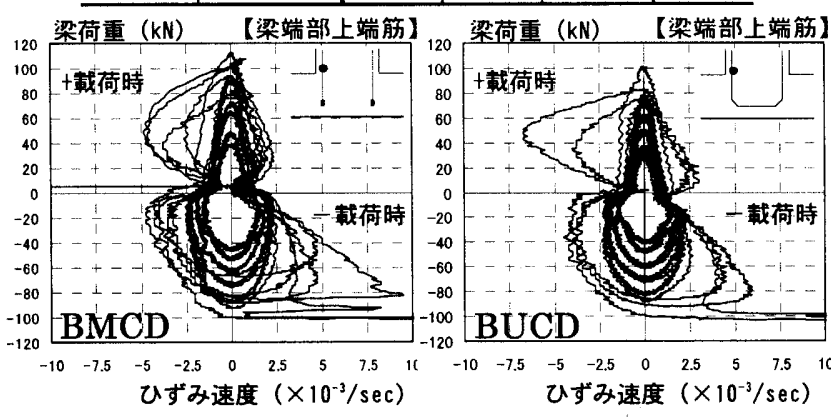

図 11 鉄施のひずみ測定結果から評価したひずみ速度
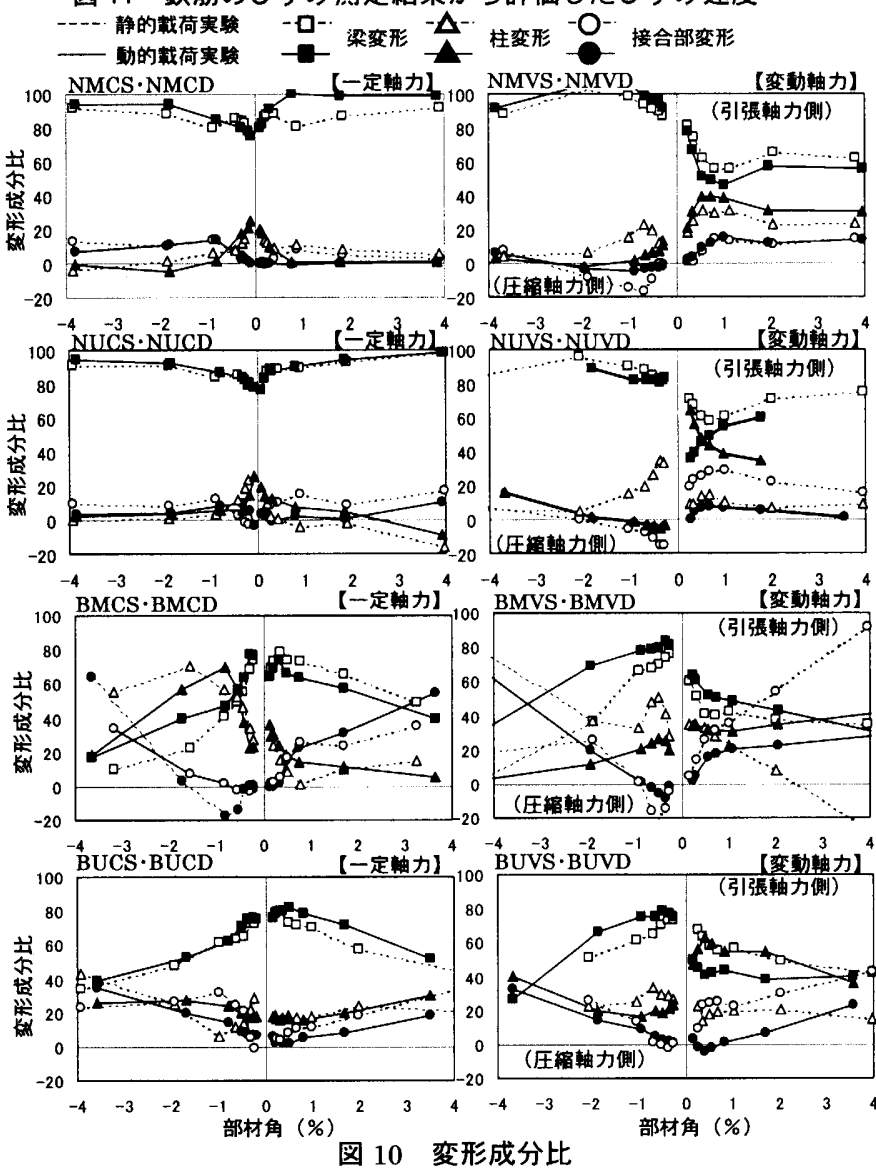

2）变動粙力（V）下における部材举動の特征

変動軸力が作用した試験体（BMVS，BMVD，BUVS，BUVD）で は一定軸力下より接合部の破壊が顕著であった。静的載荷した試験 体（BMVS, BUVS）の引張軸力下では, 柱材軸に直角方向に生ずる 引張ひび割れが発生したが, 動的載荷時（BMVD, BUVD）ではあ まり発生しなかった。また静的に比べ動的載荷ではひび割れ本数が 少なく破壊が特定のひび割れに集中し, 静的より破壊が軽微である という傾向は Nシリーズと同様である。

各試験体で荷重-変形曲線は, 一定軸力と同様に逆 $\mathrm{S}$ 字形の履歴 性状を示した。変動軸力下の試験体 (BMVS, BMVD, BUVS, BUVD) において最大耐力は, 引張軸力側よりも圧縮軸力側の方が大きくな り，引張軸力側は柱主筋が引張降伏した。

\section{2 变形成分にみる部荷速度の影量}

載荷方法や定着方法, 軸力変動の有無が履歷性状に及ぼす影響を 詳細に検討するために，加力点で計測された変位を図 7 に示す梁, 柱, 接合部の各変形成分に分離した。N及び B シリーズの各試験体 の変形成分比と制御変位(部材角)の関係を図 10 に示した。Nシリー ズでは，全体変位に対する梁変形の占める割合が最大耐力に至るま で非常に大きいが，変動軸力の引張軸力下では接合部及び柱変形の 占める割合が大きくなる傾向にある。B シリーズでは，初期の段階 で梁変形の割合は約 $80 \%$ を占めているが, 変形が進むと伴に接合部 変形の割合が大きくなる。この傾向は機械式定着の試験体(BMCS, BMCD，BMVS，BMVD）で顕著である。変動軸力が作用する動的 載荷した試験体（NUVD，BMVD，BUVD）の引張軸力時では, 静 的より動的載荷時の方が接合部変形成分は減少する傾向がある。

\section{3 ひずみ速度}

\section{1）梁端のひずみ润定桔果から求めたひずみ速度}

表 4 に動的載荷した各試験体の梁材端主筋のひずみより求めた最 大ひずみ速度を示す。また，図 11 に BMCD と BUCD 試験体の梁材 端部主筋のひずみより求めたひずみ速度の履歴を示す。ひずみ速度 は計測インターバル毎のひずみの時間的変化量として計算した。な お，表 4 の鉄筋のひずみ速度とは正負繰返し載荷において梁端部主 箭が引張を受けた時の最大ひずみ速度であり，コンクリートのひず み速度とは同主筋で圧縮を受けた時の最大ひずみ速度である。図 11 のひずみ速度の履歴において，正加力側では梁端部上端筋が圧縮を 受けるが，コンクリートも圧縮力を負担するため，ひずみ速度は比 較的小さい。一方, 負加力側では梁端部上端筋のみが引張を負担す るため，ひずみ速度は大きくなる。また，梁荷重ゼロ点で制御変形 量の增大に伴なってひずみ速度が小さくなるくびれ現象が見られた。 この現象は，荷重 - 変形曲線における荷重ゼロ近傍の明暸なスリッ プ現象からも推測されるように，梁主筋の抜け出しが原因と考えら れる。ひずみ速度は負加力側の最大耐力近傍で主筋の降伏に伴い, 顕著に大きくなる傾向が見られる。そのひずみ速度の最大值は表 4 に示されるように，引張と圧縮でばらつきはあるが，約 10-1/secか ら 10-3/sec の範囲にある。

\section{2 ）接合部の变位洞定喆果から求めたひずみ速度}

既に図 7 で示したように, 本実験では接合部の詳細な挙動を把握 するために接合部の鉛直 $(\mathrm{X} 4, \mathrm{X} 5)$, 水平 $(\mathrm{X} 6, \mathrm{X} 7)$, 対角 $(\mathrm{X} 8, \mathrm{X} 9)$ 各相対 変位を測定している。この変位測定結果を用いると接合部パネルの 変形状態は図 12 に示すように 3 辺の変位量を確定できる 4 つの三 角形要素として分解することができる。これら三角形が有限要素法 による一定ひずみ三角形要素と考えると(4)式に示す節点変位 $\left(\delta_{\mathrm{g}}\right)-$ ひずみ( $\varepsilon)$ 関保式から各三角形要素内のひずみ分布が求められる ${ }^{14)}$ 。

$$
\left.\{\varepsilon\}=[B] \delta_{g}\right\}
$$

$\{\varepsilon\}: x y$ 面内のひずみ

$\left\{\delta_{g}\right\}:$ 節点変位ベクトル

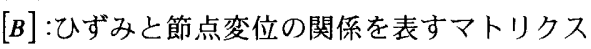

接合部にひび割れが発生すると, 接合部内には明暸な圧縮帯がで きると考えられる。各三角形要素内のひずみ分布から求めた主ひず みより接合部コンクリートに作用するひずみ速度について検討した。 なお，4つの三角形要素から各主ひずみが求められ, 計測インター バル毎の主ひずみの変化量から接合部コンクリートのひずみ速度を 求めた。図 13 に BMCD 試験体を例にひずみ速度の履歴が明瞭な三 
角形要素 1 と三角形要素 4 について示した。瞬間的に大きなひずみ 速度が得られているデータを除くと, 最大で約 $2.5 \sim 5.0 \times 10^{-2} / \mathrm{sec}$ で ある。平均ひずみ速度は, 約 $1.0 \sim 2.0 \times 10^{-2} / \mathrm{sec}$ である。これを接合 部内の平均的なコンクリートのひずみ速度と仮定すると, 梁材端主 筋の圧縮ひずみから評価したひずみ速度の約 10 倍の値であった。

\section{4.最大耐力に及ぼす戴荷速度の影到}

先に述べたように, 静的載荷実験に比べ動的載荷実験では全試験 体で最大耐力が上昇した。この動的載荷実験における耐力上昇の要 因が鉄筋やコンクリートの経験するひずみ速度の上昇による材料強 度の上昇であるという既往の研究 ${ }^{15), 16)}$ に基づいて検討を行った。

\section{1 ）ひずみ速度による材料强度推定式}

ひずみ速度の増加に伴って上昇する鉄筋の降伏点強度とコンク

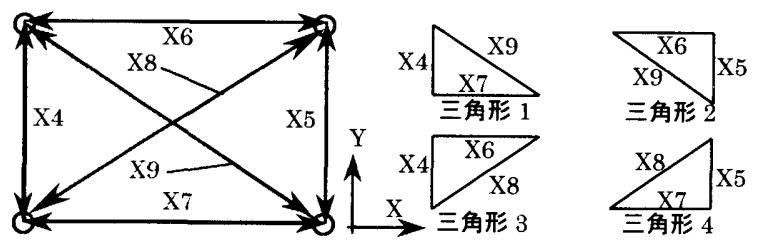

図 12 接合部内の三角形要素

\section{【BMCD 試涘体】}

梁荷重 (kN)【三角形 1]
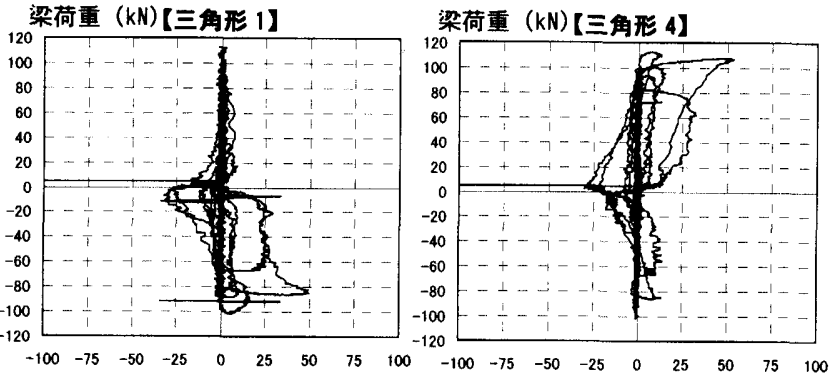

ひずみ速度 $\left(\times 10^{-3} / \mathrm{sec}\right)$

ひずみ速度 $\left(\times 10^{-3} / \mathrm{sec}\right)$
リートの圧縮強度は(5)，(6) 式によって与えられるものとする ${ }^{15), 16) 。 ~}$

$$
\begin{aligned}
f_{y u}^{\prime} & =f_{y u}(1.20+0.05 \log \dot{\varepsilon}) \\
F^{\prime}{ }_{y u} & =F_{y u}(1.38+0.08 \log \dot{\varepsilon})
\end{aligned}
$$

$\left(\mathrm{N} / \mathrm{mm}^{2}\right) \quad(6)$

$f_{y u}$ : 鉄筋の静的降伏点強度 $f^{\prime}{ }_{y u}$ : 鉄筋の動的降伏点強度 $F_{y u}$ :

コンクリートの静的圧縮強度 $F^{\prime}{ }_{y u}$ : コンクリートの動的圧縮強

度 $\dot{\varepsilon}:$ ひずみ速度 $(1 / \mathrm{sec})$

（5）（6）式においてひずみ速度の適用範囲は， $10^{-3} \sim 10^{-1}(1 / \mathrm{sec）}$ 程度である。また, 鉄筋は降伏点強度が $410\left(\mathrm{~N} / \mathrm{mm}^{2}\right)$ ，コンクリー 卜は圧縮強度が $45\left(\mathrm{~N} / \mathrm{mm}^{2}\right)$ 以下で適用される。なお, 本研究では 梁主筋に使用した高強度鉄筋 D19（SD490）に関しても，(5) 式を 適用した。動的載荷実験から得られた鉄筋及びコンクリートが経験 した最大ひずみ速度を上式に代入した鉄筋の降伏点強度とコンクリ ートの圧縮強度を表 5 に示した。コンクリートにおいては梁端部の 圧縮側梁主筋のひずみ速度と同等として評価した場合と前節で求め た主ひずみにおける最大ひずみ速度より評価した場合を併せて示す。 表 2 に示す通常の材料強度と比較すると鉄筋では, 9 〜 18\%降伏点強 度が上昇した。コンクリートでは圧縮鉄筋による評価で 19 ～29\%， 主ひずみによる評価で 25３5\% 上昇するという結果となった。

\section{2）ひずみ速度による材料強度上升を考礼した請强度计策值}

表 6 の諸強度計算値のうち, 静的載荷した試験体の値は表 2 に示 した材料強度を, 動的載荷した試験体の值は表 5 に示した材料強度 を使用した。なお，コンクリート圧縮強度に関して，接合部せん断 強度は, 接合部主ひずみから求めたコンクリート圧縮強度を用い, 定着強度は圧縮主筋のひずみ速度から求めたコンクリート圧縮強度 を使用した。表 6 の括弧内の値は各終局強度計算値に対する実験值 最大耐力の比を表し, 実験値は正負加力側の平均値とした。

$\mathrm{N}$ シリーズの試験体では, 実験值最大耐力は梁曲げ強度計算値之 よく対応しており，また，載荷速度の上昇による材料強度の上昇を 考慮した動的載荷試験体の曲げ終局強度計算値において も，実験值をほぼ同等に評価している。一方，B シリー ズの試験体では, 梁曲げ強度と接合部せん断強度を拮抗 させて設計しており，双方の強度計算值は，いずれも実

\begin{tabular}{|c|c|c|c|c|c|c|c|c|}
\hline 試锒体(Nタイブ) & \multicolumn{2}{|c|}{ NMCD } & \multicolumn{2}{|c|}{ NUCD } & \multicolumn{2}{|c|}{ NMVD } & \multicolumn{2}{|c|}{ NUVD } \\
\hline 梁主筋随伏点強度 $\left(\mathrm{N} / \mathrm{mm}^{2}\right)$ & \multicolumn{2}{|c|}{694} & \multicolumn{2}{|c|}{689} & \multicolumn{2}{|c|}{459} & \multicolumn{2}{|c|}{428} \\
\hline コンクリート & 圧樎鉄筋 & 主ひずみ & 压綿鉄解 & 主ひずみ & 压耤鉄筋 & 主ひずみ & 压耤鉄筇 & 主ひずみ \\
\hline 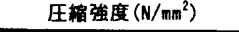 & 54.6 & 58.0 & 55.1 & 58.5 & 32.3 & 34.9 & 23.7 & 25.2 \\
\hline 式确体 (Bタイブ) & \multicolumn{2}{|c|}{ BMCD } & \multicolumn{2}{|c|}{ BUCD } & \multicolumn{2}{|c|}{ BMVD } & \multicolumn{2}{|c|}{ BUVD } \\
\hline 梁主筋降伏点強度 $\left(\mathrm{N} / \mathrm{mm}^{2}\right)$ & \multicolumn{2}{|c|}{452} & \multicolumn{2}{|c|}{448} & \multicolumn{2}{|c|}{458} & \multicolumn{2}{|c|}{423} \\
\hline コンクリート & 压䧿鉄筋 & 主ひずみ & 圧綰鉄筋 & 主ひずみ & 压編鉄篆 & 主ひずみ & 压綰鉄筋 & 主ひずみ \\
\hline 圧缩強度 $\left(\mathrm{N} / \mathrm{mm}^{2}\right)$ & 31.3 & 33.4 & 22.5 & 24.0 & 31.3 & 33.4 & 22.3 & 23.8 \\
\hline
\end{tabular}
験値とよく対応した結果を得た。動的載荷した試験体に

\begin{tabular}{|c|c|c|c|c|c|c|c|c|c|c|c|c|c|}
\hline \multirow{3}{*}{ 試験体 } & \multirow{2}{*}{\multicolumn{2}{|c|}{$\begin{array}{c}\text { 実験值 } \\
\text { 最大耐力 }(k N) \\
\end{array}$}} & \multicolumn{6}{|c|}{ 終局強度計算值 ${ }^{(1)}(\mathrm{kN})$} & \multirow{3}{*}{$\begin{array}{c}\text { 接合部せん断 } \\
\text { 余裕度 } \\
\mathrm{P}_{\mathrm{su}} / \mathrm{P}_{\mathrm{fu}}\end{array}$} & \multirow{3}{*}{$\begin{array}{c}\text { 上㫒染 } \\
(\%)\end{array}$} & \multirow{3}{*}{$\begin{array}{c}\text { 定着 } \\
\text { 余裕度 } \\
\mathrm{P}_{\mathrm{au}} / \mathrm{P}_{\mathrm{fu}}\end{array}$} & \multirow{3}{*}{$\begin{array}{c}\text { 上开率 } \\
(\%)\end{array}$} & \multirow{3}{*}{$\begin{array}{l}\text { 破塿 } \\
\text { 形式 }\end{array}$} \\
\hline & & & \multirow{2}{*}{\multicolumn{2}{|c|}{ 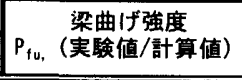 }} & \multirow{2}{*}{\multicolumn{2}{|c|}{$\begin{array}{c}\text { 接合部せん断強度 } \\
\mathrm{P}_{\text {su, }} \text { (実験值/計算值) }\end{array}$}} & \multirow{2}{*}{\multicolumn{2}{|c|}{$\begin{array}{c}\text { 定着强度 } \\
\mathrm{P}_{\mathrm{au}} \text { (実倹值/計算値) }\end{array}$}} & & & & & \\
\hline & 正加力 & 負加力 & & & & & & & & & & & \\
\hline NMCS & 93.0 & 80.0 & 77.6 & $(0.90)$ & 122.8 & $(1.42)$ & 80.4 & $(0.93)$ & 1.58 & - & 1.04 & - & $\overline{\mathrm{BT}}$ \\
\hline MMCD & 93.3 & 87.1 & 93.6 & $(1.04)$ & 155.0 & $(1.72)$ & 86.5 & $(0.96)$ & 1.66 & 4.6 & 0.92 & -11.2 & BT \\
\hline NUCS & 80.6 & 74.1 & 77.6 & $(1.00)$ & \begin{tabular}{|l|}
122.8 \\
\end{tabular} & $(1.59)$ & \begin{tabular}{|l|}
65.9 \\
\end{tabular} & $(0.85)$ & 1.58 & - & 0.85 & - & BT \\
\hline NUCD & 85.0 & 79.4 & 92.9 & $(1.13)$ & \begin{tabular}{|l|}
156.0 \\
\end{tabular} & $(1.90)$ & 74.0 & $(0.90)$ & 1.68 & 6.0 & 0.80 & -5.8 & $B$ \\
\hline NMVS & 71.8 & 76.7 & 61.0 & $(0.82)$ & 93.1 & $(1.25)$ & \begin{tabular}{|l|}
73.3 \\
\end{tabular} & $(0.99)$ & 1.53 & - & 1.20 & - & B \\
\hline NAVO & 75.5 & 80.6 & $67.1 !$ & $(0.86)$ & 114.7 & $(1.47)$ & 79.7 & $(1.02)$ & 1.71 & 12.0 & 1.19 & -1.0 & $B$ \\
\hline NUVS & 60.8 & 63.6 & 58.0 & $(0.93)$ & \begin{tabular}{|l|}
72.9 \\
\end{tabular} & $(1.17)$ & \begin{tabular}{|l|}
71.7 \\
\end{tabular} & $(1.15)$ & 1.26 & - & 1.24 & - & $B$ \\
\hline NUVD & 68.2 & 69.4 & 66.6 & $(0.97)$ & 91.3 & $(1.33)$ & 78.2 & $(1.14)$ & 1.37 & 9.1 & 1.17 & -5.3 & $\bar{B}$ \\
\hline BMCS & 106.2 & 91.8 & 95.6 & $(0.97)$ & 93.6 & $(0.95)$ & 122.1 & $(1.23)$ & 0.98 & - & 1.30 & - & B \\
\hline BMCD & 112.5 & 101.3 & 110.2 & $(1.03)$ & 111,2 & $(1.04)$ & 131.4 & $(1.23)$ & 1.01 & 3.1 & 1.18 & -9.6 & B \\
\hline BUCS & 82.8 & 82.0 & 94.6 & $(1.15)$ & \begin{tabular}{|l|}
72.9 \\
\end{tabular} & $(0.88)$ & 87.5 & $(1.06)$ & 0.77 & - & 1.20 & - & $\mathrm{J}$ \\
\hline BUCD & 100.5 & 102.9 & 109.2! & $(1.07)$ & 94.5 & $(0,39)$ & 93.5 & $(0.92)$ & 0.87 & 12.3 & 0.99 & -17.5 & BJ \\
\hline BMVS & 93.0 & 99.5 & 95.6 & $(0.99)$ & 93.6 & $(0.97)$ & 122.1 & $(1.27)$ & 0.98 & - & 1.30 & - & JB \\
\hline BMVD & 98.0 & 104.3 & 111.6 & $(1.10)$ & 111.2 & $(1.10)$ & 131.4 & $(1.30)$ & 1.00 & 1.8 & 1.18 & -9.6 & JB \\
\hline BUVS & 74.4 & 88.0 & 94.6 & $(1.17)$ & 72.9 & $(0.90)$ & 87.5 & $(1.08)$ & 0.77 & - & 1.20 & - & $\mathrm{JB}$ \\
\hline BUVD & 91.1 & 100.8 & 103.1: & $(1.07)$ & 93.9 & $(0.98)$ & 93.2 & $(0.97)$ & 0.91 & 18.2 & 0.99 & -17.5 & $\overline{B J}$ \\
\hline
\end{tabular}

表 6 実験値最大耐力と終局強度計算値及び破壊形式

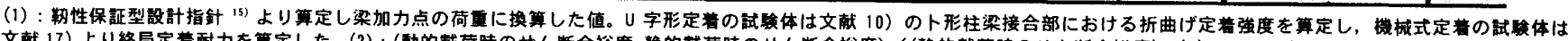
文到

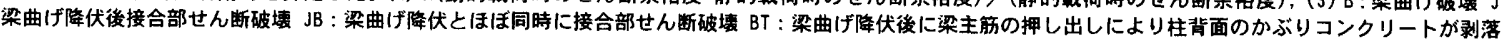


おいても同様である。また、いずれの試験体とも実験値と計算値が 近似した結果を得た推定式から推測される破壊モードは実駼結果と 良く対応している。

\section{3）接合部せん断余裕度及ひ定来余裕度と破壇形式}

表 6 に接合部せん断余裕度及び定着余裕度と実験で観測された破 壊形式を併せて示す。接合部せん断余裕度は梁曲げ強度に対する接 合部せん断強度の比とし，定着余裕度は梁曲げ強度に対する定着強 度の比と定義した。

静的載荷と動的載荷で破壊モードに差異が生じた試験体の破壊 形式と接合部せん断余裕度及び定着余裕度の関倸について検討する と, 静的載荷を行った NUCS は梁曲げ降伏後の定着破壊であったも のが, 動的載荷(NUCD)では梁曲げ降伏のみで定着破壊は生じなかっ た。せん断余裕度の小さいBタイプの試験体では，BUCS が接合部 せん断破壊であったものが BUCD では梁曲げ降伏後の接合部せん 断破壊に, BUVS と BUVDでは梁曲げ降伏と接合部せん断破壊がほ ぼ同時に起こる破壊から梁曲げ降伏後の接合部せん断破壊へと変化 した。表 6 には，載荷速度の上昇による材料強度の上昇を考慮した 場合のせん断余裕度及び定着余裕度と動的載荷時の各々の上昇率を 示しているが，接合部せん断破壊が遅れる傾向にあった BU シリー ズの試験体は，せん断余裕度が 0.77 と最も低く，かつ，せん断余裕 度の上昇率が $12.3 \sim 18.2 \%$ と他の試験体に比べ著しく大きな試験体 であった。一方，動的載荷時に定着破壊が生じなかったNU シリー ズの試験体は, 定着余裕度が 0.85 と最も低い試験体であり, かつ, 定着余裕度の上昇率は-5.8\%の試験体であった。上昇率が負の值で あるため計算上は定着破壊がより生じやすくなる試験体であるが， 上昇率が小さなこと, また, 計算上の破墙形式が側方割裂破壊であ るのに対し，実呀では梁曲げ降伏後に梁主筋の押し出しによる柱背 面のかぶりコンクリートが剥落する破壊形式であったことが，計算 上の傾向と実験結果に違いを生じさせたものと考える。

\section{4. まとめ}

\section{【接合部せん断余裕度の高い证酸体（Nシリース）】}

1) 動的載荷実験では, 静的載荷実験に比べて接合部のひび割れは明 らかに減少する傾向が見られた。

2) 機械式定着の試験体では, 静的載荷時に接合部外側の柱主筋に沿 う割裂状のひび割れが発生し，U 字形定着の試験体とは異なる破 壊性状を示した。動的載荷時においても同様の破壊を起こした。

3) 履歴性状は, 静的及び動的載荷時ともに紡鍾形を示し, 全ての試 験体で，梁主筋の降伏後に接合部横補強筋が降伏した。

4) 変動軸力の引張軸力下における接合部の破壊は一定軸力下より も顕著である。接合部せん断余裕度を十分に確保することにより， 変動軸力下でも接合部性能を健全に維持することが可能となる。

\section{【接合部せん断余﨏度の低い拭确体（Bシリーズ）】}

5)U 字形定着に比べ機械式定着した試験体では，動的載荷実験にお いて，接合部及び柱背面のひび割れが顕著であった。

6) 機械式定着した試験体は，静的及び動的載荷時ともに，接合部で 発生したせん断ひび割れが柱外側の主筋に沿って進展するとい う特徵的な破壊状況が $\mathrm{N}$ シリーズよりも顕著にみられた。最大耐 力後このひび割れの発生に伴い，機械式定着した全ての試験体で は，柱背面のかぶりコンクリートの剥落と同時に柱主筋が大きな
圧縮力を負担し座屈した。

7)一定軸力下より変動軸力下の方が, 接合部の破壊は厳しくなる傾 向が見られた。また，変動軸力下では，載荷速度の上昇に伴い， 柱の曲げひび割れは減少し，接合部にひび割れが集中した。

8) 静的及び動的載荷時ともに接合部横補強筋の降伏後に梁主筋が 降伏し，逆 S 字形の履歷性状を示した。

9)変動軸力下の引張軸力時には全試験体で柱主筋が曲げ降伏し, 最 大耐力後の耐力の低下は緩やかである。一方，圧縮軸力時には接 合部横補強笳が降伏し，かぶりコンクリートの剥落とともに，耐 力低下している。特に機械式定着の試験体で顕著である。

\section{【取大涌力に及ぼす就荷速度の影需】}

10)載荷速度が上昇すると，実験值最大耐力は上昇する。動的載荷時 のひずみ速度から推定した材料強度を用いて計算した終局強度 は，実駼結果と良く対応した。

11)上述したように載荷速度の上昇により最大耐力は上昇するが, 履 歴性状は静的と動的載荷時であまり差異はみられない。

12)本実験での載荷速度の上昇による破壊モードの変化は，せん断余 裕度の上昇と対応した。一方, 計算上で定着余裕度は低下するが, 破壊モードに影響は見られなかった。

\section{【襱】}

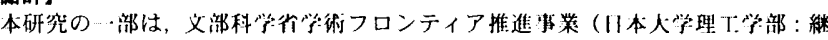

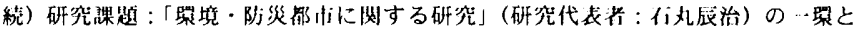
して夹施されたものである。威倸芥条位に感謝の意を柿します。

\section{【考文䴢}

1）日本建築兴会：鉄筋コンクリート建物の終局強度型耐敌設計指針・同解説， 1990.11

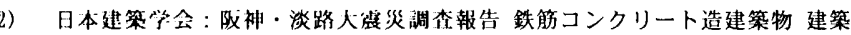
編 $1,1997.7$

3）村上:雅英，藤達也，筐四敏行：はり筋を機械式定着した外柱・はり接合部

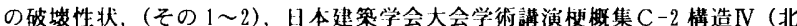
海道), pp99-102, 1995.8

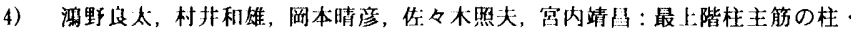
梁接合部への定着法に関する研究（その1T型骨組による加力実験）、日本 建策学会大会学術講演梗概集 C 構造 II (東海)，pp681-682，1994.8

5）村井和雄, 吉田憵喜, 岡本晴彦, 宫内靖月：端部にコブを設けた染主能の柱 梁接合部内における定着性能に関する怣験的研究（その3〜4），日本建築学 会大会学術講演梗概集C梅造 II (東海)，pp683-686，1994.8

6）奥田明久，中西:利，安達洋：機械式定着法を用いた鉄筋コンクリート造卜 型柱梁接命部の力学的性状に及ほす载荷速度の影郎に関する実験的研究（そ の 1 3), 日本建策学会大会学術講演梗概集 C-2 構造IV (近畿), pp601-606, 1996.9

7）山田高史，中西三和，安達洋：鉄觔コンクリート造卜型柱梁接合部の静的お 上び動的載荷実駼, 日本建築学会大会学術講演梗概集 C - 2 構造 $\mathrm{V}($ その 1 2) (九州)，pp545-548，1998.9

8）山田高史，中西三和，安達洋，青山博之：変動軸力を受ける鉄筋コンクリー 卜造外柱梁接合部の力学的性状に関する実験的研究（その $1 \sim 3$ ）, 日本建築 学会大会学術講演梗概集 C-2 構造IV (中国)，pp971-976，1999.9

9）小岛陽一，中西三和，安達洋，青山博之：変動軸力を受ける機械式定着法 用いた鉄筋コンクリート造ト形柱梁接合部の挙動に関する実験的研究（その 1 3), 日本建策学会大会学術講演梗概集 C-2 構造 N (北陸), pp571-576, 2002.8

10）日本建築学会：鉄筋コンクリート建物の勒性保証型耐震設計指針・同解説, 1999.8

11）日本建築学会：鉄筋コンクリート構造計算規準・同解説, 1999.11

12）牛丸裕，小野新，田草川正光，中西三和，白井伸明，安達洋：変動軸力を受 ける鉄筋コンクリート造柱の弾塑性性状に関する研究（その $3 \sim 5)$ ， 日本建 築学会大会学術講演梗概集 C構造 II (中国), pp855-864, 1990.10

13）梅村魁，青山博之，伊藤勝：棰造実験と構造設計，技報堂 1973.

14）Y.C.ファン：連続体の力学入門，培風館 1985.10

15）小谷俊介：鉄筋コンクリートにおける載荷速度の影響，コンクリート工学, Vol.21, No.11, pp23-33Nov. 1983

16) W. H. Dilger, R. Koch, R. Kowalczyk:Ductility of Plain and Confined Concrete under Differeni Strain Rales, ACI Journal, 1984, 1-2.

17）東京鉄鋼株式会社：プレートナット工法設計施工指針，1999

（2005年 7 月 10 日原稿受理， 2005 年11月 14 日採用決定） 